\title{
Inactivation of yeast inorganic pyrophosphatase by organic solvents
}

\author{
RODRIGO GRAZINOLI-GARRIDO and MAURO SOLA-PENNA \\ Laboratório de Enzimologia e Controle do Metabolismo (LabECoM), Departamento de Fármacos \\ Faculdade de Farmácia, Universidade Federal do Rio de Janeiro - UFRJ \\ 21941-590 Rio de Janeiro, RJ, Brasil
}

Manuscript received on October 22, 2003; accepted for publication on May 26, 2004; presented by Lucia Mendonça Previato

\begin{abstract}
A number of application for enzymes in organic solvents have been developed in chemical processing, food related conversions and analyses. The only unsolved problem related to nonaqueous enzymology is the notion that enzymes in organic solvent are mostly far less active than in water. Therefore, studies concerning the mechanisms by which enzymes are inactivated by organic solvents would reveal a clear understanding of the structure-function relationship of this phenomenon. Here we analyzed the effects of a series of alcohols (methanol, ethanol, 1-propanol and 2-propanol) and acetone on the activity of yeast inorganic pyrophosphatase. We observed that solvents inactivated the enzyme in a dose-dependent manner. This inactivation is also dependent on the hydrophobicity of the solvent, where the most hydrophobic solvent is also the most effective one. The $\mathrm{I}_{50}$ for inactivation by $n$-alcohols are $5.9 \pm 0.4,2.7 \pm 0.1$ and $2.5 \pm 0.1 \mathrm{M}$ for methanol, ethanol and 1-propanol, respectively. Inactivation was less effective at $37^{\circ} \mathrm{C}$ than at $5^{\circ} \mathrm{C}$, when the $\mathrm{I}_{50}$ for inactivation by methanol, ethanol and 1-propanol are $4.5 \pm 0.2,2.1 \pm 0.2$ and $1.7 \pm 0.1 \mathrm{M}$, respectively. Our proposal is that solvent binds to the enzyme structure promoting the inactivation by stabilizing an unfolded structure, and that this binding is through the hydrophobic regions of either the protein or the solvent.
\end{abstract}

Key words: organic solvents, enzyme, yeast inorganic pyrophosphatase, alcohol.

\section{INTRODUCTION}

The ability to use enzymes in non-aqueous solvents greatly expands the potential applications of biocatalysts in chemical transformations useful for many industries. There are many potential advantages of enzyme catalysts in non-aqueous solvents: (a) increased solubility of substrates such as lipids and phospholipids, (b) novel chemistry in synthetic application, (c) altered substrate specificity, (d) easier product recover, and (e) reduced microbial con-

Correspondence to: Mauro Sola-Penna

E-mail: maurosp@ufrj.br tamination (Dordick 1989, Khmelnistsky and Rich 1999, Song and Rhee 2002). However, almost all natural enzymes are easily denatured or inactivated by organic solvents. Therefore, numerous chemical and physical methods for activating and/or stabilizing enzymes in organic media have been developed. (Lopes and Sola-Penna 2001, Mine et al. 2001).

Since the characterized properties of an enzyme in aqueous environment may be dramatically altered by the substitution of water with organic solvents (Klibanov 1989) a clear understanding of the structure-function relationship between the solvent of choice and the enzyme would provide useful in- 
formation for many practical purposes (Miroliaei and Nemat-Gorgani 2002). It has been suggested that both the unfolding and inactivation events of the conventional $\mathrm{N} \leftrightarrow \mathrm{U} \rightarrow$ I model can be markedly decreased in hydrophobic media (Fágáin 1995). Also, when a protein molecule is placed in a hydrophobic environment, in which the deleterious covalent reactions are much less likely to occur, water's effective concentration is dramatically reduced (Fágáin 1995, Zaks and Klibanov 1988, Ahern and Klibanov 1985).

Despite the proposed higher stability in organic solvents, enzymes typically exhibit substantial reduced activity in organic solvents (Lopes and Sola-Penna 2001, Guo and Clark 2001). Several factors contribute to the low activity of enzymes in organic media, including structural changes in active site, dehydration of molecule domains and poor compatibility between the solvent and transition state (Guo and Clark 2001). Therefore, to take full advantage of the benefits revealed by nonaqueous enzymology, several mechanistic issues need to be elucidated (Klibanov 2001). For this reason the study of the denaturation/inactivation of enzymes in organic solvents should contribute to a better understanding of the mechanisms involved on the organic solvent inactivation phenomenon.

Here we show the effects of alcohols and acetone on inactivation of yeast inorganic pyrophosphatase, in an attempt to elucidate some of the mechanisms involved on the stability of enzymes in less polar hydrophilic media. These solvents were used as water-soluble organic solvent models, in order to investigate the denaturation of enzyme in a less polar aqueous solution. This enzyme, an important regulator of eukaryotic metabolism, controlling the catabolism of aminoacids and nucleotides, has been used elsewhere as a model for enzyme denaturation/inactivation (Lopes and Sola-Penna 2001, SolaPenna and Meyer-Fernandes 1998) and for bioenergetics modeling studies (De Meis 1989). We believe that the data presented on this paper would allow us to suggest some of the mechanisms involved on the inactivation of enzyme on organic solvents.

\section{MATERIALS AND METHODS}

\section{Materials}

Yeast inorganic pyrophosphatase (EC 3.6.1.1) exhibiting high purity (99.5\%) was purchased from Sigma Chemical Co. (St. Louis, MO) catalog number I-1643. Other reagents were of the highest purity available.

\section{Methods}

\section{Determination of pyrophosphatase activity}

The enzyme activity assay was performed at $5^{\circ} \mathrm{C}$ or at $37^{\circ} \mathrm{C}$ in $0.4 \mathrm{ml}$ of a medium containing $100 \mathrm{mM}$ Hepes-Tris (pH 7.5), $5 \mathrm{mM} \mathrm{MgCl}_{2}, 150 \mathrm{mM} \mathrm{KCl}$, $2 \mathrm{mM}$ tetrasodium pyrophosphate, and $0.8 \mu \mathrm{g}$ of purified enzyme per milliliter of reaction medium. Pyrophosphatase activity was determined by measuring the total Pi released at the end of assay. The Pi concentration was determined as described elsewhere (Lowry and Lopez 1946). Reaction was quenched $3 \min \left(5^{\circ} \mathrm{C}\right)$ or $1 \min \left(37^{\circ} \mathrm{C}\right)$ after addition of enzyme, when the formation of products is linear in function of time, by addition of 2 volumes of colorimetric reagent.

\section{Curve fitting}

Curves were fitted to experimental data by nonlinear regression using the software SigmaPlot for Windows 7.0 (Jandel Scientific, USA).

\section{RESULTS AND DISCUSSION}

Yeast inorganic pyrophosphatase activity was measured in the presence of increasing concentrations of alcohols at $5^{\circ} \mathrm{C}$ and at $37^{\circ} \mathrm{C}$. Figure 1 shows the inactivation of this enzyme, in a dose-dependent manner at both temperatures, promoted by all alcohols tested. The inactivation is due to an unfolding of pyrophosphatase tertiary structure induced by alcohols, following the model: $\mathrm{N} \leftrightarrow \mathrm{U} \rightarrow \mathrm{I}$. The binding of alcohol molecules to protein structure would shift the equilibrium towards the unfolded (U) configuration, leading the enzyme to an inactive state. According to this, the data of pyrophosphatase inacti- 
vation by increasing concentrations of alcohols can be used to fit the parameters of equation:

$$
v=v o * K i /\left(K i+A^{n}\right),
$$

where $v$ is the enzyme activity at each alcohol concentration $(A), v o$ is the velocity in the absence of alcohols, $K i$ is the inactivation constant and $n$ is the cooperativity index. In this way, the $\mathrm{I}_{50}$ (concentration of solvent that promotes half of the maximum inactivation) can be calculated and used to evaluate the effectiveness of inactivation of pyrophosphatase promoted by the solvents.

Table I summarizes the calculated $\mathrm{I}_{50}$ for the results presented on Figure 1. As it can be seen, this parameter significantly decreases as the aliphatic chain length of the alcohol used increases in both temperatures. In this way, methanol is the least potent inactivator $\left(\mathrm{I}_{50}=4.5 \pm 0.2\right.$ and $5.9 \pm 0.4 \mathrm{M}$ for $5^{\circ} \mathrm{C}$ and $37^{\circ} \mathrm{C}$, respectively, the cooperativity index, $\mathrm{n}$, were $2.5 \pm 0.3$ and $1.6 \pm 0.2$ for $5^{\circ} \mathrm{C}$ and $37^{\circ} \mathrm{C}$, respectively), followed by ethanol $\left(\mathrm{I}_{50}\right.$ $=2.1 \pm 0.2$ and $2.7 \pm 0.1 \mathrm{M}$ for $5^{\circ} \mathrm{C}$ and $37^{\circ} \mathrm{C}$, respectively, the cooperativity index, $\mathrm{n}$, were $1.8 \pm 0.2$ and $1.9 \pm 0.2$ for $5^{\circ} \mathrm{C}$ and $37^{\circ} \mathrm{C}$, respectively), and 1-propanol been the most potent among tested alcohols $\left(\mathrm{I}_{50}=1.7 \pm 0.1\right.$ and $2.5 \pm 0.1 \mathrm{M}$ for $5^{\circ} \mathrm{C}$ and $37^{\circ} \mathrm{C}$, respectively, the cooperativity index, $\mathrm{n}$, were $3.2 \pm 0.3$ and $2.1 \pm 0.2$ for $5^{\circ} \mathrm{C}$ and $37^{\circ} \mathrm{C}$, respectively). These data suggest that inactivation of inorganic pyrophosphatase by alcohols depends on the hydrophobicity of the solvent. Other investigators have made similar observations using pure organic solvents (Lopes and Sola-Penna 2001, Klibanov 1989, Miroliaei and Nemat-Gorgani 2002, Fágáin 1995, Zaks and Klibanov 1988, Ahern and Klibanov 1985, Lopes et al. 1999, Volkin et al. 1991). These investigators have concluded that in high hydrophobic media, enzyme exposes hydrophobic regions that would lead to an inactivation of the catalyst. However, it has not been stated clear whether this would happens in a water/solvent mixture, since the preferential hydration phenomena could make the interaction between water and protein more favorable (Lopes and Sola-Penna 2001, Timasheff 1998).
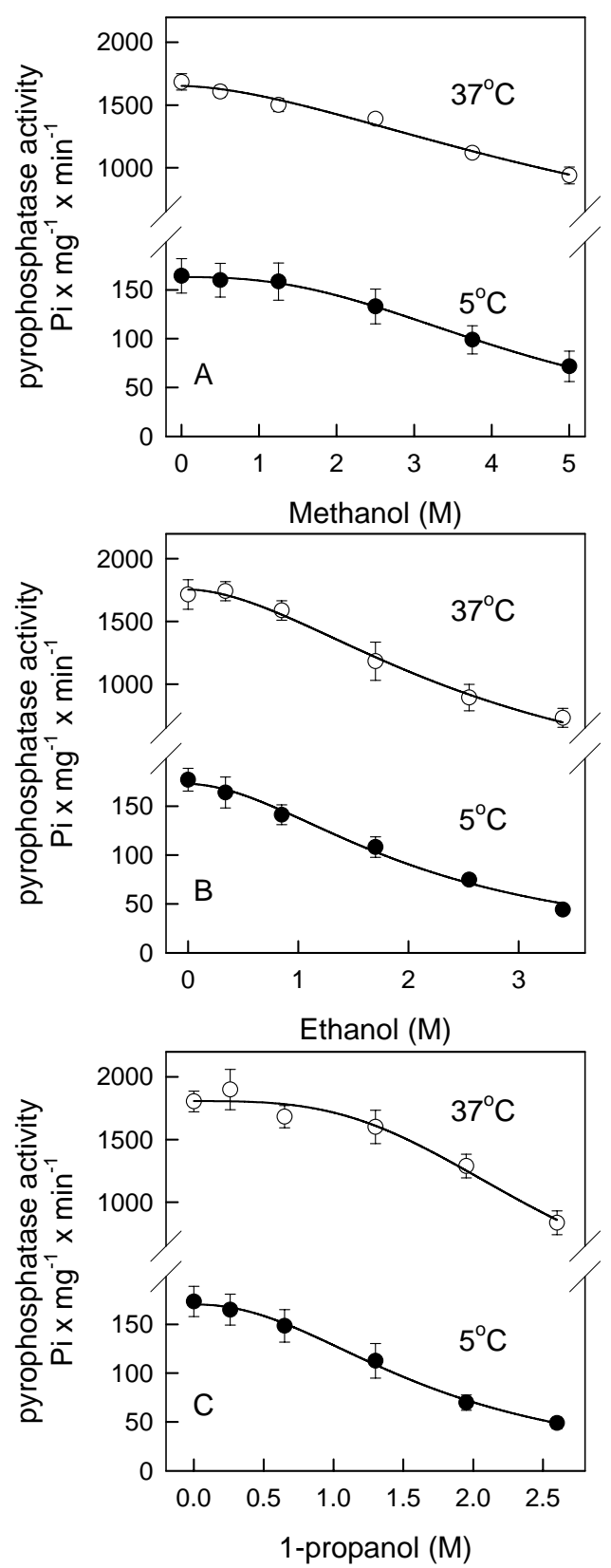

Fig. 1 - Inactivation of yeast inorganic pyrophosphatase by alcohols. Reaction was performed as described under Materials and Methods at $5^{\circ} \mathrm{C}(\bullet)$ and $37^{\circ} \mathrm{C}(\circ)$ in the presence of the concentrations of methanol (panel A), ethanol (panel B) and 1-propanol (panel C) indicated on abscissa. Data points represent means \pm SE of four independent experiments $(n=4)$. Lines are calculated adjusting the parameters of equation 1 to the experimental data. 
In order to confirm the dependence on solvent hydrophobicity, we analyzed the effects of the 3carbon solvents: 1-propanol, 2-propanol and acetone on the inactivation of yeast inorganic pyrophosphatase. Figure 2 shows the inactivation of the enzyme induced by these solvents. Significant differences were obtained only among assays performed at $5^{\circ} \mathrm{C}(p<0.05)$. It is noteworthy that the effectiveness on inactivation of pyrophosphatase increases with increasing hydrophobicity (expressed as $\log P$, where $P$ is the partition coefficient between octan-1-ol and water, 18) of the organic solvents. Thus 1-propanol with the highest $\log P(0.25)$ provided the most effective inactivation $\left(\mathrm{I}_{50}=1.7 \pm\right.$ $0.1 \mathrm{M}$, with a cooperativity index, $\mathrm{n}$, of $2.8 \pm 0.3$ ), followed by 2-propanol $\left(\log P=0.05, \mathrm{I}_{50}=2.1 \pm\right.$ $0.2 \mathrm{M}$, with a cooperativity index, n, of $2.4 \pm 0.3$ ) and acetone $\left(\log P=-0.24, \mathrm{I}_{50}=2.5 \pm 0.1 \mathrm{M}\right.$, with a cooperativity index, $\mathrm{n}$, of $2.1 \pm 0.2$ ). Table II summarizes the calculated $\mathrm{I}_{50}$ for data presented on Figure 2. There are no significant differences among data obtained at $37^{\circ} \mathrm{C}$. However, comparing the $\mathrm{I}_{50}$ calculated from data at $5^{\circ} \mathrm{C}$ with their counterparts obtained at $37^{\circ} \mathrm{C}$, it can be seen that at higher temperature the enzyme is more resistant to inactivation promoted by the organic solvents (Table I and Table II), what could allow us to propose that hydrophobic interactions, which are more strong at higher temperatures, are playing and important role on the stabilization of this enzyme against the organic solvents.

Several enzymes are described to be more thermostable in organic solvents than in aqueous solutions (Volkin et al. 1991, Hansch et al. 1995, Tsitsimpikou et al. 1994). Actually, Zacks and Klibanov (1984) pointed out that water has a dual effect on an enzyme: it is essential for maintenance of its native conformation and is also involved in the mechanisms of the inactivation processes. Here we used mixtures of alcohols or acetone with water, in a highly hydrophilic media, and our results were not much different from those obtained with pure hydrophobic organic solvents (Klibanov 1989, Miroliaei and Nemat-Gorgani 2002, Fágáin 1995, Zaks and
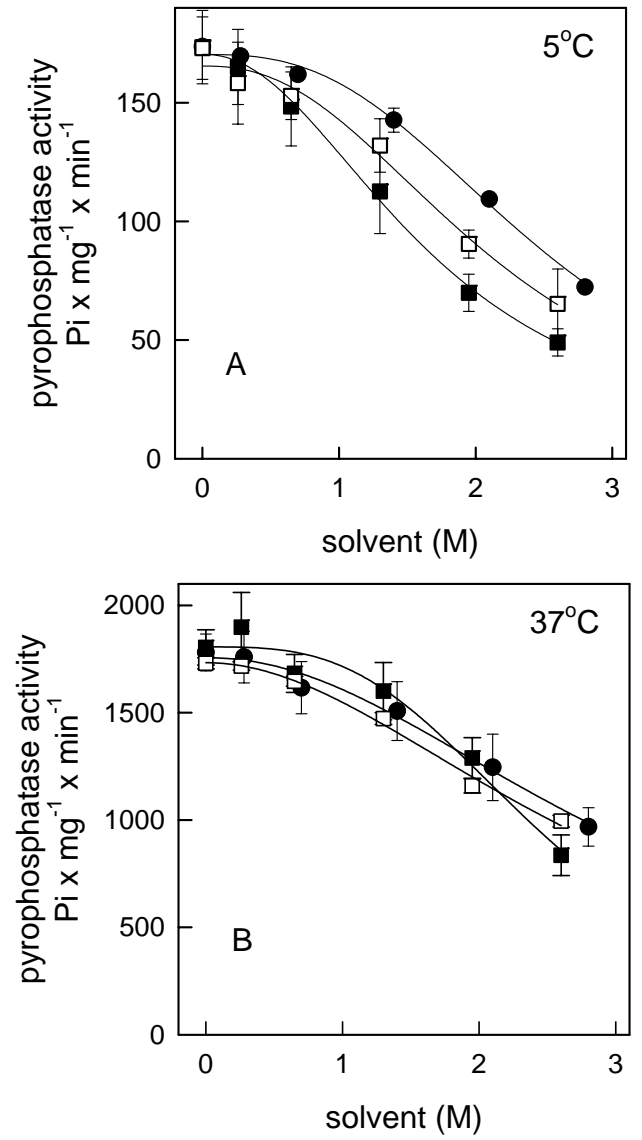

Fig. 2 - Inactivation of yeast inorganic pyrophosphatase by 3carbon organic solvents. Reaction was performed as described under Materials and Methods at $5^{\circ} \mathrm{C}$ (panel A) and $37^{\circ} \mathrm{C}$ (panel B) in the presence of the concentrations of 1-propanol ( $\square)$, 2propanol $(\square)$ and acetone $(\bullet)$ indicated on abscissa. Data points represent means $\pm S E$ of four independent experiments $(n=4)$. Lines are calculated adjusting the parameters of equation 1 to the experimental data.

Klibanov 1988, Ahern and Klibanov 1985, Volkin et al. 1991, Hansch et al. 1995, Tsitsimpikou et al. 1994). We showed that the enzyme is inactivated by the organic solvent depending on the hydrophobicity of the solvent, and that the effectiveness of the inactivation decreases at higher temperatures. Our data show that the enzyme is more stable at higher temperatures, supporting the observations of the literature (Volkin et al. 1991, Hansch et al. 1995, Tsitsimpikou et al. 1994). Indeed, when an en- 
TABLE I

$\mathbf{I}_{50}$ and cooperativity index, $\mathbf{n}$, for the inactivation of yeast inorganic pyrophosphatase by alcohols.

\begin{tabular}{l|c|c|c|c}
\hline & \multicolumn{2}{|c|}{$5^{\circ} \mathrm{C}$} & \multicolumn{2}{c}{$37^{\circ} \mathrm{C}$} \\
\hline Solvent & $\mathrm{I}_{50}(\mathrm{M})$ & $\mathrm{n}$ & $\mathrm{I}_{50}(\mathrm{M})$ & $\mathrm{n}$ \\
\hline Methanol & $4.5 \pm 0.2^{\mathrm{a}}$ & $2.5 \pm 0.3$ & $5.9 \pm 0.4^{\mathrm{d}}$ & $1.6 \pm 0.2$ \\
\hline Ethanol & $2.1 \pm 0.2^{\mathrm{b}}$ & $1.8 \pm 0.2$ & $2.7 \pm 0.1^{\mathrm{e}}$ & $1.9 \pm 0.2$ \\
\hline 1-propanol & $1.7 \pm 0.1^{\mathrm{c}}$ & $3.2 \pm 0.3$ & $2.5 \pm 0.1^{\mathrm{f}}$ & $2.1 \pm 0.2$ \\
\hline
\end{tabular}

$\mathrm{I}_{50}$ and $\mathrm{n}$ are represented as means \pm SE of four independent experiments. $\mathrm{a}$ is different from $\mathrm{b}, \mathrm{c}$, and $\mathrm{d}(p<0.05)$. $\mathrm{b}$ is different from $\mathrm{c}$ and $\mathrm{e}(p<0.05)$. $\mathrm{c}$ is different from $\mathrm{f}(p<0.05)$. $\mathrm{d}$ is different from $\mathrm{e}$ and $\mathrm{f}(p<0.05)$. e is different from $\mathrm{f}(p<0.05)$.

\section{TABLE II}

I $_{50}$ for inactivation of yeast inorganic pyrophosphtase by organic solvents.

\begin{tabular}{l|c|c|c|c|c}
\hline \multicolumn{2}{l|}{} & \multicolumn{2}{c}{$5^{\circ} \mathrm{C}$} & \multicolumn{2}{c}{$37^{\circ} \mathrm{C}$} \\
\hline Solvent & $\log P^{\mathrm{a}}$ & $\mathrm{I}_{50}(\mathrm{M})$ & $\mathrm{n}$ & $\mathrm{I}_{50}(\mathrm{M})$ & $\mathrm{n}$ \\
\hline 1-propanol & 0.25 & $1.7 \pm 0.1^{\mathrm{b}}$ & $2.8 \pm 0.3$ & $2.5 \pm 0.1^{\mathrm{e}}$ & $2.8 \pm 0.3$ \\
\hline 2-propanol & 0.05 & $2.2 \pm 0.2^{\mathrm{c}}$ & $2.4 \pm 0.3$ & $3.0 \pm 0.3^{\mathrm{f}}$ & $2.4 \pm 0.3$ \\
\hline acetone & -0.24 & $2.5 \pm 0.1^{\mathrm{d}}$ & $2.1 \pm 0.2$ & $3.2 \pm 0.2^{\mathrm{g}}$ & $2.1 \pm 0.2$ \\
\hline
\end{tabular}

$\mathrm{I}_{50}$ and $\mathrm{n}$ are represented as means \pm SE of four independent experiments. a is the partition coefficient between octan-1-ol and water (17). b is different from $\mathrm{c}, \mathrm{d}$ and e $(p<0.05)$. $\mathrm{c}$ is different from $\mathrm{d}$ and $\mathrm{f}(p<0.05)$. $\mathrm{d}$ is different from $\mathrm{g}(p<0.05)$. There are NO differences between $\mathrm{d}$, e and $\mathrm{f}(p>0.05)$.

zyme is in water/alcohol mixtures, conditions that usually stabilize protein structure and function can instead promote an inactivation effect on enzymes (Lopes and Sola-Penna 2001), while conditions that would usually account to an unfolded protein configuration can stabilize an active enzyme (Lopes and Sola-Penna 2001, Guo and Clark 2001).

We proposed here that the inactivation phenomenon is achieved through the binding of solvent molecules to enzyme structure. This is also supported by literature data (Lopes and Sola-Penna 2001). Since the effectiveness of inactivation increases with the hydrophobicity of the solvent, one can suggest that more hydrophobic solvents have higher affinity for the enzyme than less hydrophobic ones. This is supported by the $\mathrm{I}_{50}$ data presented on Tables I and II. These solvents might be binding to the hydrophobic regions of the enzyme, exposing them to the bulk, unfolding and consequently inactivating the catalyst.

\section{ACKNOWLEDGMENTS}

We thank Dr. Tatiana El-Bacha for the critical reading of this manuscript. This work was submitted to the Faculdade de Farmácia - UFRJ, by R.G.G. in partial fulfillment of requirements for degree of Master in Pharmaceutical Sciences. This project was supported by Programa de Apoio ao Desenvolvimento Científico e Tecnológico (PADCT), Fundação Carlos Chagas Filho de Amparo à Pesquisa do Estado do Rio de Janeiro (FAPERJ), Conselho Na- 
cional de Desenvolvimento Científico e Tecnológico (CNPq), Programa de Apoio a Núcleos de Excelência (PRONEX). R.G.G. was recipient of graduate fellowship from Coordenação de Aperfeiçoamento de Pessoal de Nível Superior (CAPES).

\section{RESUMO}

Várias aplicações para a catálise enzimática em solventes orgânicos têm sido desenvolvidas visando processos químicos, industria alimentícia e métodos analíticos. Entretanto, o único problema ainda não resolvido para estas aplicações é o fato que estes catalisadores são bem menos ativos nestas condições que em meio aquoso. Assim, estudos dos mecanismos pelos quais as enzimas são inativadas em solventes orgânicos podem facilitar a compreensão da interrelação estrutura/função da interação entre os catalisadores e o solvente. Neste trabalho, nós analisamos os efeitos de uma série de álcoois (metanol, etanol, 1propanol e 2-propanol) e de acetona na atividade catalítica da pirofosfatase inorgânica de leveduras. Foi observado que os solventes inativaram a enzima de uma maneira que dependia da concentração do solvente no meio. Além disso, a inativação dependia da hidrofobicidade do solvente. $\mathrm{O}_{50}$ para a inativação promovida pelos álcoois primários foi $5.9 \pm 0.4,2.7 \pm 0.1$ e $2.5 \pm 0.1 \mathrm{M}$ para metanol, etanol e 1-propanol, respectivamente. A inativação foi menos efetiva a $37^{\circ} \mathrm{C}$ do que a $5^{\circ} \mathrm{C}$, onde o $\mathrm{I}_{50}$ para a inativação por metanol, etanol and 1-propanol foi $4.5 \pm 0.2,2.1 \pm 0.2$ e $1.7 \pm 0.1 \mathrm{M}$, respectivamente. Nossa proposta é que o solvente liga-se à estrutura proteica, promovendo a inativação, e que esta ligação se dá através da região hidrofóbica do solvente e da proteína.

Palavras-chave: solventes orgânicos, enzima, pirofosfatase inorgânica de leveduras, alcoóis.

\section{REFERENCES}

Ahern TJ And Klibanov AM. 1985. The mechanism of irreversible enzyme inactivation at $100^{\circ} \mathrm{C}$. Science 228: 1280-1283.

De MeIs L. 1989. Role of water in the energy of hydrolysis of phosphate compounds: energy transduction in biological membranes. Biochim Biophys Acta 973: 333-349.

DoRDICK JS. 1989. Enzymatic catalysis in monophasic organic solvents. Enzyme Microb Technol 11: 194211.
FÁGÁIN CÓ. 1995. Understanding and increasing protein stability. Biochim Biophys Acta 1252: 1-14.

Guo Y and Clark DS. 2001. Activation of enzymes for nonaqueous biocatalysis by denaturing concentrations of urea. Biochim Biophys Acta 1546: 406411.

Hansch C, Leo A and Hoekman D. 1995. Exploring QSAR: Hydrophobic, electronic, and steric constants. Am Chem Soc, Washington.

Khmelnistsky YL AND Rich JO. 1999. Biocatalysis in nonaqueous solvents. Current Opinion in Chem Biol 3: $47-53$.

KLIBANOv AM. 1989. Enzymatic catalysis in anhydrous organic solvents. Trends in Biochemical. Science 14: $141-144$

KLibanov AM. 2001. Improving enzymes by using them in organic solvents. Nature 409: 241-246.

Lopes DHJ ANd Sola-Penna M. 2001. Urea increases tolerance of yeast inorganic pyrophosphatase activity to ethanol: the other side of urea interaction with proteins. Arch Biochem Biophys 394: 61-66.

Lopes DHJ, Meyer-Fernandes JR and Sola-Penna M. 1999. Effects of trehalose and ethanol on yeast cytosolic pyrophosphatease. Z Naturforsch 54c: 186190.

LOWRY HO AND Lopez JA. 1946. The determination of inorganic phosphate in the presence of labile phosphate esters. J Biol Chem 162: 421-428.

Mine Y, Kimitoshi F, Yoshimoto M, Nakao K AND Sugimura Y. 2001. Modification of lipase with poly(ethylene glycol) and poly(oxyethylene) detergents and their catalytic activities in organic solvents. J Biosci Bioeng 92: 539-543.

Miroliaei M and Nemat-Gorgani M. 2002. Effect of solvents on stability and activity of two related alcohol dehydrogenases: a comparative study. Int $\mathbf{J}$ Biochem Cell Biol 34: 169-175.

Sola-Penna M And Meyer-Fernandes JR. 1998. Stabilization against thermal inactivation promoted by sugars on enzyme structure and function: why is trehalose more effective than other sugars? Arch Biochem Biophys 360: 10-14.

SoNG JK AND RHEE JS. 2002. Enhancement of stability of phospholipase $A_{1}$ in organic solvents by directed evolution. Biochim Biophys Acta 1547: 370-378. 
TimashefF SN. 1998. Control of protein stability and reactions by weakly interacting cosolvents: the simplicity of the complicated. Adv Protein Chem 51: 355-432.

Tsitsimpikou C, Voutou D, Christakopoulos P, Kekos D, Macris BJ ANd Kolisis FN. 1994. Studies of the effect of organic solvents on the stability of bglucosidase from Fusarium oxysporum. Biotechnol Lett 16: 57-62.
Volkin DB, Staubli A, Langer R and Klibanov AM. 1991. Enzyme thermoinactivation in anhydrous organic solvents. Biotechnol Bioeng 37: 843-853.

ZaKs A AND KLiBAnOv AM. 1984. Enzymatic catalysis in organic media at $100^{\circ} \mathrm{C}$. Science 224: 1249-1251.

ZaKs A And KLIBAnOv AM. 1988. The effect of water on enzyme action in organic media. J Biol Chem 263: 8017-8021. 